\title{
Jejunal injuries in captive marmosets affected by chronic wasting disease
}

\section{Lesões jejunais em saguis cativos afetadas pela doença do emagrecimento progressivo crônico}

Washington Luiz Assunção Pereira' (D), José Antônio Picanço Diniz Junior² (D), José Augusto Pereira Carneiro Muniz $^{3}$ (D), Alex Junior Souza de Souza ${ }^{4}$ (D), Fernanda Figueiredo Mendes ${ }^{1}$ (D), Amanda Desirée Assunção Cecim ${ }^{5}$, Lucien Roberta Valente Miranda de Aguirrab (iD

' Universidade Federal Rural da Amazônia, Instituto de Produção e Saúde Animal, Laboratório de Patologia Animal, Belém, Pará, Brasil

2 Instituto Evandro Chagas/SVS/MS, Laboratório de Microscopia Eletrônica, Belém, Pará, Brasil

${ }^{3}$ Instituto Evandro Chagas/SVS/MS, Centro Nacional de Primatas, Ananindeua, Pará, Brasil

${ }^{4}$ Instituto Evandro Chagas/SVS/MS, Seção de Hepatologia, Belém, Pará, Brasil

${ }^{5}$ Instituto Evandro Chagas/SVS/MS, Laboratório de Virologia, Belém, Pará, Brasil

6 Universidade Federal Rural da Amazônia, Instituto de Produção e Saúde Animal, Programa de Pós-Graduação em Saúde e Produção Animal na Amazônia, Belém, Pará, Brasil

\begin{abstract}
INTRODUCTION: Wasting marmoset syndrome affects the Callitrichidae family reared in captivity, characterized by progressive muscle-weakening and wasting conditions. It has been one of the main causes of death in primates of this genus. OBJECTIVE: To evaluate the existence of histopathological and ultrastructural alterations in jejunal of marmosets that presented a clinical history of the progressive wasting disease in relation to healthy animals. MATERIALS AND METHODS: Jejunal biopsies of seven marmosets were performed: five of them, two specimens of Callithrix jacchus and three Callithrix penicillata, were affected by clinical signs of progressive weight loss and muscle weakness; and two healthy animals, one of each cited species, were used as control animals. RESULTS: Marmosets with a clinical history of progressive weight loss presented jejunal villus atrophy with a flattened surface; also the goblet cells were scarce and barely functional compared to the control animals. CONCLUSION: These changes can cause malabsorption of nutrients and promote the progressive weight loss of callitrichids.
\end{abstract}

Keywords: Callithrix; Intestinal Mucosa; Intestinal Diseases; Malabsorption Syndromes.

\section{RESUMO}

INTRODUÇÃO: A síndrome do emagrecimento progressivo afeta a família Callitrichidae criada em cativeiro, caracterizada por emagrecimento progressivo e enfraquecimento muscular, tendo sido uma das principais causas de morte em primatas desse gênero. OBJETIVO: Avaliar a existência de alterações histopatológicas e ultraestruturais do jejuno dos primatas que apresentavam história clínica da síndrome do emagrecimento progressivo em relação aos animais saudáveis. MATERIAIS E MÉTODOS: Foram realizadas biópsias jejunais em sete saguis: cinco deles, dois Callithrix jacchus e três Callithrix penicillata, afetados por sinais clínicos de perda progressiva de peso e fraqueza muscular; e dois animais saudáveis, um de cada espécie citada, usados como animais controle. RESULTADOS: Animais com histórico clínico de perda progressiva de peso apresentaram atrofia das vilosidades do jejuno com superfície achatada; além disso, as células caliciformes eram escassas e pouco funcionais comparadas às dos animais controle. CONCLUSÃO: Essas mudanças podem causar má absorção de nutrientes e promover a perda progressiva de peso de calitriquídeos.

Palavras-chave: Callithrix; Mucosa Intestinal; Doenças Intestinais; Síndrome da Má Absorção.

\section{Correspondence / Correspondência:}

Washington Luiz Assunção Pereira

Universidade Federal Rural da Amazônia, Instituto de Produção e Saúde Animal, Laboratório de Patologia Animal

Av. Presidente Tancredo Neves, 2501. Bairro: Terra Firme. CEP: 66077-830 - Belém, Pará, Brazil - Phone \# : +55 (91) $3210-5139$

E-mail:wkarton@terra.com.br 


\section{INTRODUCTION}

Callitrichids, generally called marmosets, are neotropical primates of the New World belonging to the Callitrichidae family'. They are omnivorous, with good reproductive efficiency in captivity, and widely used as experimental models in biological studies ${ }^{2}$. However, they are animals with gastrointestinal sensitivity and usually develop diseases culminating in poor digestion and malabsorption syndrome ${ }^{3}$.

One of the main problems observed in captive marmosets is characterized by a clinical condition of chronic weight loss, muscle weakness, nonresponsive diarrhea, and death, which is currently known as a chronic wasting disease (CWD), a severe disease that occurs in colonies of callitrichids all over the world ${ }^{4}$. It is a syndrome with unestablished etiology and represents a significant cause of mortality in captive callitrichids ${ }^{5}$. It has a chronic feature, high morbidity and mortality 6,7 . CWD generally manifests progressive weight loss, continuous and nonresponsive diarrhea, anemia, pelvic limb paralysis, tail alopecia, and severe muscle atrophy, culminating in animals' death after two or three months $s^{6,7}$.

The dietary variety that animals have in the natural environment - based on fruits, small insects or vertebrates, and plants - is essential for their health. Captive marmosets are susceptible to develop intestinal disorders because of the supply of industrialized animal food, which is cited as a determining factor for the occurrence of CWD and infectious or metabolic diseases, characterizing it as a syndrome of probable multifactorial origin ${ }^{8}$.

The maintenance of non-human primates in captivity represents a form of wildlife conservation as well as a source for research and better understanding about these animals. CWD in callitrichids of captive colonies represents a significant cause of mortality and a challenge in maintaining their diet. The present study aimed to evaluate possible changes of the histological and ultrastructural analysis of jejunal portions of animals affected by CWD and to clarify the pathophysiology of this disease.

\section{MATERIALS AND METHODS}

\section{ANIMALS AND STUDY DESIGN}

This study was developed from August 2004 to July 2005 at the Centro National de Primatas (CENP), located at the Ananindeua municipality, Pará State, Brazil (latitude $1^{\circ} 38^{\prime} 26^{\prime \prime}$ and longitude 48 $\left.38^{\prime} 22^{\prime \prime}\right)$, following the requirements of the Brazilian Society of Science in Laboratory Animals. The study protocol was approved by the Committee on Animal Research and Ethics of the Instituto Evandro Chagas ( $\mathrm{n}^{\circ}$ 005/2003) under technical decision $n^{\circ}$ 0007/2004.

Seven adult marmosets were used: five of them, two Callithrix jacchus (one male and one female) and three Callithrix penicillata (two males and one female), which had a progressive fat loss, muscle weakness, dorsal and caudal alopecia, and paresis of pelvic limbs, were selected by clinical and historical characteristics of CWD; and two healthy male animals, one of each species, C. jacchus and C. penicillata, were used as control animals.

All study specimens were obtained from the breeding shed. They were kept in stainless steel cages, in family groups of the same species, and received a diet with fruits, vegetables, eggs, milk, dog food (Foxy Premium Júnior $\left.^{\circledR}\right)$, and water ad libitum.

A jejunal biopsy was performed on all animals. The samples were submitted to histopathological and ultrastructural examination for morphological evaluation by light microscopy and transmission electron microscopy to identify and characterize the jejunal lesions in the specimens affected by CWD.

\section{INTESTINAL BIOPSY}

Prior to the intestinal biopsies, the animals were submitted to a 12-hour fast from food, a 6-hour fast from water, and chemical restraint using dissociative anesthesia induced by the combination of ketamine (50 mg/ $\mathrm{kg})$, midazolam (0.2 to $0.5 \mathrm{mg} / \mathrm{kg}$ ) and levomepromazine $(0.2$ to $0.5 \mathrm{mg} / \mathrm{kg})$ intramuscularly.

Intestinal biopsies were performed by surgical removal of the jejunal ring segment, followed by suturing of the remaining intestinal segments. From each biopsy specimen, two to three fragments of $1.0 \mathrm{~mm}$ were collected for transmission electron microscopy, while the remaining sample was kept for histopathology procedures.

The postoperative period was based on daily bandage with rifamycin and Alantol $^{\circledR}$ (Vetnil, São Paulo, Brazil) on the surgical wound, twice a day, for seven days. A liquid diet was provided on the first postoperative day, followed by a paste diet for the next four days. In addition, the animals were treated with a daily application of antibiotics (clindamycin), intravenously for five days, $\mathrm{K}$ vitamin, and non-steroidal anti-inflammatory (flunixin meglumine) intramuscularly, once a day, for three days.

\section{HISTOPATHOLOGY}

Samples obtained by biopsies were fixed in 10\% neutral buffered formalin dehydrated embedded in histological wax, cut off $5 \mu \mathrm{m}$ thick sections using the hematoxylin and eosin (H\&E) technique for the histological characterization of eventual intestinal lesions caused by CWD.

\section{TRANSMISSION ELECTRON MICROSCOPY}

Jejunum fragments of approximately $1 \mathrm{~mm}^{3}$ were fixed in $4 \%$ formaldehyde and $2.5 \%$ glutaraldehyde in a $0.1 \mathrm{M}$ sodium cacodylate buffer solution, with $\mathrm{pH} 7.2$, for $2 \mathrm{~h}$ at room temperature. Subsequently, the fragments were washed in the same buffer, post-fixed for $1 \mathrm{~h}$ in a buffered solution containing 1\% osmium tetroxide, $0.8 \%$ ferrocyanide, and $5 \mathrm{mM}$ calcium chloride, rewashed in the same buffer, dehydrated in graded acetone, and embedded in epoxy resin. Thin sections were mounted on copper grids, stained with uranyl acetate and lead citrate, and examined in Zeiss EM 900 Transmission Electron Microscopy. 


\section{RESULTS}

Five animals of this study considered affected by CWD showed clinical signs of progressive weight loss, even though they were hungry. They also presented diarrhea, poor vocalization, and lateral back alopecia of the thorax, pelvic limbs, and tail (Figure 1A).

In the jejunal histopathological analysis of animals with CWD, isolated lymphoid nodules and mucosa-associated lymphoid tissue cells were intact in the connective tissue of the mucosa and submucosa. In two cases, the goblet cells were smaller and less functional compared to other cases. Superficially, the glycocalyx was shown to be a fine acidophilic line. The jejunal villus was short and flattened (Figure 1B) compared to control animals (Figure 1C). In enterocytes, the microvilli presented irregular distribution, being absent in some segments. Severe villus atrophy and malabsorption were observed. Cells from the intestinal crypts showed adequate mitoses.

Biopsies of other intestine segments of the animals affected by CWD were not analyzed, and microscopic alterations compatible with inflammation in the jejunal segment were not observed.

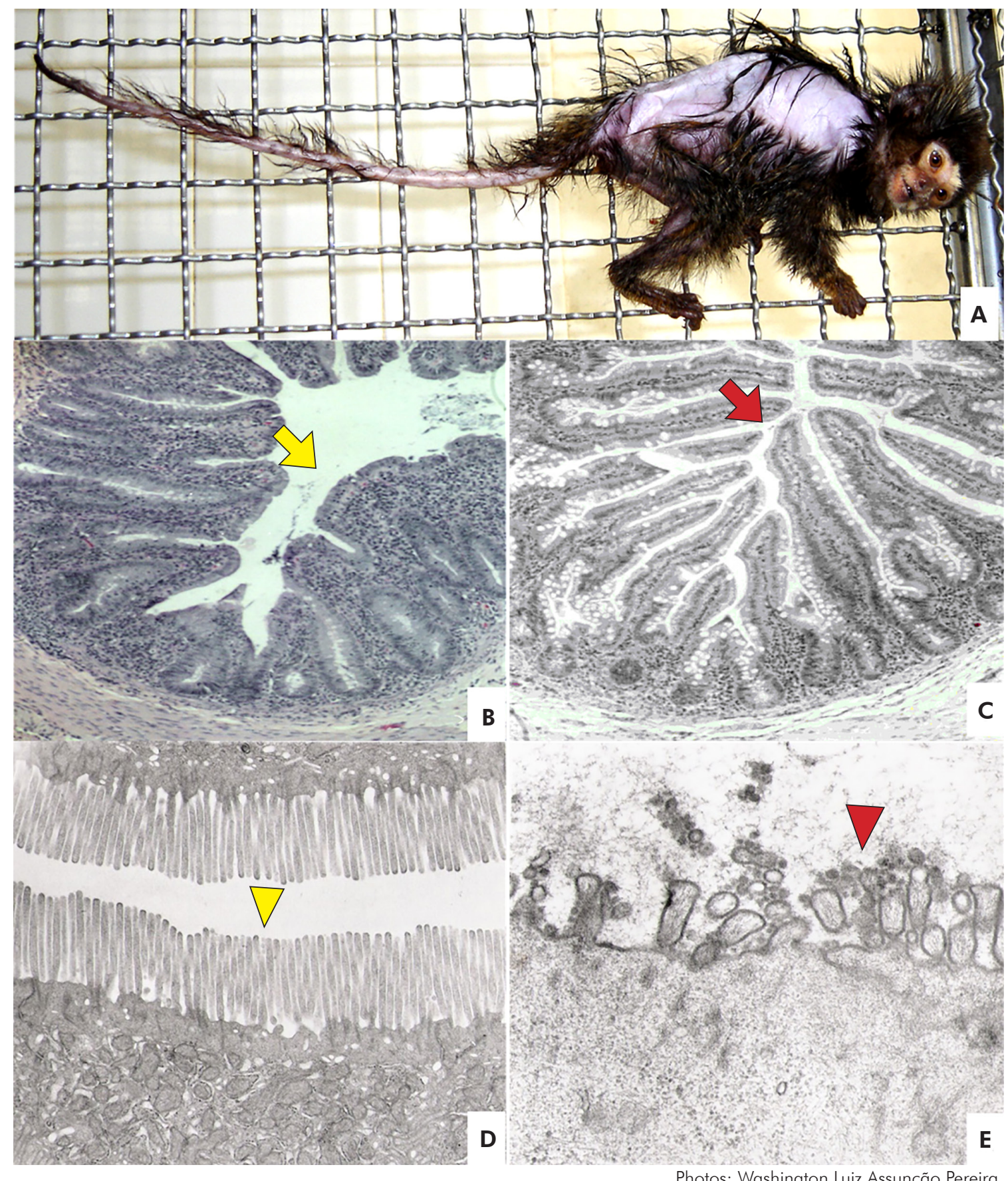

A: Callithrix jacchus kept in captivity in the CENP, with the presence of lateral back alopecia of the thorax, pelvic limbs, and tail, compatible with clinical signs of CWD. B: Jejunal animal biopsy with CWD presenting villus atrophy (yellow arrow) (HE, 200x). C: Photomicrography of jejunal biopsy from control animal. Normal villus (red arrow) (HE 200x). D: Electron microscopy of jejunal biopsy. Normal microvilli of control animals (yellow arrowhead). E: Electron microscopy of jejunal biopsy from animal with CWD showing atrophy and destruction of microvilli (red arrowhead).

Figure 1 - Clinical and pathological aspects of CWD 
The ultrastructural study of jejunal biopsies showed that control animals had intact villus and microvilli and did not present alterations in their structure (Figure 1D). On the other hand, the samples from animals with CWD presented alterations of atrophy and destruction of microvilli (Figure 1E).

\section{DISCUSSION}

According to Yoshimoto et al. ${ }^{9}$ and Gore et al. ${ }^{8}$, the main characteristic of CWD is the marked loss of body condition of animals with persistent muscular hypotrophy. Moraes et al. ${ }^{10}$ reported, in addition, chronic and unresponsive diarrhea, muscle weakness. In this context, Schroeder et al. ${ }^{11}$ observed progressive cachexia, tail alopecia, nephritis, and intermittent diarrhea, corroborating with the clinical findings observed in this study.

Moraes et al. ${ }^{10}$ reported that CWD was described in newly weaned primates and subsequently expanded to include marmosets of any age. In this sense, all animals of the present study diagnosed with CWD were adults and survived, on average, three months after the symptoms appeared, corroborating the findings of Diniz $^{6}$ and Yoshimoto et al. ${ }^{12}$. In addition, Sá ${ }^{5}$ observed that this disease affects captive callitrichids of different species and both sexes, like what was observed in this experiment.

The histopathological findings of this study were different from those described by $\mathrm{Sá}^{5}$; no inflammation or any surface parasitic form was observed. In view of this, severe atrophy of villus and malabsorption were found, the same as described by Sdepanian et al. ${ }^{13}$ in human celiac disease.

When studying non-human primates affected by CWD, Sás stated that these animals had chronic immune-mediated enteritis comparable with human celiac disease, with loss of the absorptive surface of the small intestine and secondary malnutrition, identical to what was observed in the present study.

Sources of protein such as wheat, soybeans, and milk are included in the diet of several callitrichids farms. However, an experiment by Gore et al. ${ }^{8}$ demonstrated that the gliadin protein, present in wheat, can cause an immune reaction in Saguinus oedipus and C. jacchus intestine, similar to findings related to celiac disease in humans, such as mucosal villus atrophy of the small intestine, compromising the absorption of nutrients, vitamins, minerals, and water. Therefore, based on the experiment of these authors, it could be considered the possibility of an immune reaction to wheat protein, promoting the atrophy of small intestine villus of the animals in this study caused by their diet with dog food containing grains, which is not part of the natural diet of marmosets and can cause a reaction.

Moreover, Kuehnel et al. $^{3}$ demonstrated that gluten-containing diets determine the occurrence of a reaction in marmosets blood biochemistry similar to those observed in celiac disease in humans, with an increase in anti-gliadin antibody concentrations. This finding can be evidence that the diet might be the beginning of CWD in marmosets.

According to Sdepanian et al. ${ }^{13}$, the celiac disease diagnosis is made by histopathological examination of jejunal mucosa endoscopic biopsy, in which the flattening of the villus is evidenced. The same result was observed in this study.

Gozalo and Montoya ${ }^{14}$ believe that chronic exposure to the diet offered in captivity, which contains allergenic antigens, leads to the development of colitis. Among the causes of this syndrome commonly mentioned are genetic origin, stress, excessive vitamin $E$, zinc deficiency, mycoplasma infections, viral infections, poisoning by heavy metals, among other causes ${ }^{6,15}$.

Moraes et al. ${ }^{10}$ also reported as one of the causes of CWD the infection by pancreatic nematode Trichospirura leptostoma that obstructs the bile ducts; although Sousa et al. ${ }^{4}$ considered that the etiology of CWD is very difficult to determine and can be associated with Platynosomum infection.

Chalifoux et al. ${ }^{16}$ attributed CWD to the occurrence of chronic colitis, characterized by mono and polymorphonuclear infiltrates in the mucous membrane and submucous of the colon, associated with a decrease in the number of goblet cells, abscesses formation in intestinal crypts, and atypical epithelial cells. According to Logan and Khan ${ }^{17}$, chronic colitis is the most common contributory factor for CWD due to the release of inflammatory cytokines, such as tumor necrosis factor-alpha, causing loss of chronic muscle mass secondarily.

Still in relation to the causes of CWD in callitrichids, Sá ${ }^{5}$ demonstrated that the disease does not derive from protein-calorie malnutrition and steatorrhea, which indicates gastrointestinal malabsorption. It was not due to pancreatic insufficiency, since it was found active trypsin in the feces of the animals studied. Changes in diet may also be determinant to decrease the problems related to the CWD, especially regarding the protein intake imbalance and the type of the protein ${ }^{15,18}$. In this study, the control group received the same diet as the experimental group, which shows that it is not the diet alone that causes CWD. Therefore, more research is necessary to clarify its origin.

\section{CONCLUSION}

Callitrichids with CWD symptoms presented atrophy and destruction of the jejunal villus in the histopathological and ultrastructural analysis, which is a cause of malabsorption of nutrients, leading to malnutrition and loss of weight and muscles, peculiar signs of the CWD. These findings contribute to a better pathophysiology understanding of the disease and help solve this issue in captive marmosets.

\section{FINANCIAL SUPPORT}

The research was developed with support of the Instituto Evandro Chagas, Centro National de Primatas, and the Universidade Federal Rural da Amazônia. 


\section{AUTHORS CONTRIBUTION}

JAPCM was responsible for the surgeries to obtain the material for analysis. JAPDJ helped with the preparation and analysis of electron microscopy material. WLAP, AJSS, and LRVMA helped with the preparation, description, and discussion of the results of the histopathology material. FFM and ADAC were responsible for the preparation, translation, and submission of the manuscript. All authors collaborated in the discussion of the method and results obtained in this study.

\section{CONFLICTS OF INTEREST}

There are no conflicts of interest.

\section{REFERENCES}

1 Emmons LH, Feer F. Neotropical rainforest mammals: a field guide. Chicago: University of Chicago Press; 1990.

2 Orsi A, Rees D, Andreini I, Venturella S, Cinelli S, Oberto $G$. Overview of the marmoset as a model in nonclinical development of pharmaceutical products. Regul Toxicol Pharmacol. 2011 Feb;59(10):19-27.

3 Kuehnel F, Mietsch M, Buettner T, Vervuert I, Ababneh R, Einspanier A. The influence of gluten on clinical and immunological status of common marmosets (Callithrix jacchus). J Med Primatol. 2013 Dec;42(6):300-9.

4 Sousa MBC, Leão AC, Coutinho JFV, Ramos AMO. Histopathology findings in common marmosets (Callithrix jacchus Linnaeus, 1758) with chronic weight loss associated with bile tract obstruction by infestation with Platynosomum (Loos, 1907). Primates. 2008 Oct;49(4):283-7.

5 Sá LRM. Síndrome de emagrecimento progressivo dos calitriquídeos - processo de má absorção semelhante à doença celíaca humana - caracterização clínica, laboratorial e anatomopatológica [tese]. São Paulo (SP): Universidade de São Paulo, Faculdade de Medicina Veterinária e Zootecnia; 2004.

6 Diniz LSM. Primatas em cativeiro: manejo e problemas veterinários: enfoque para espécies neotropicais. São Paulo: Ícone; 1997.

7 Sá LRM, Mirandola RMS, Duarte MIS. Síndrome de emagrecimento progressivo em calitriquídeos mantidos em cativeiro é um processo de má-absorção semelhante à Doença Celíaca no homem. Anais do $5^{\circ}$ Congresso da Associação Brasileira de Veterinários de Animais Selvagens, $10^{\circ}$ Encontro da Associação Brasileira de Veterinários de Animais Selvagens; 2001 out 31-4 nov; São Paulo, BR. São Paulo: ABRAVAS; 2001. p. 22.

8 Gore MA, Brandes F, Kaup FJ, Lenzner R, Mothes T, Osman AA. Callitrichid nutrition and food sensitivity. J Med Primatol. 2001 Jun;30(3):179-84.
9 Yoshimoto T, Niimi K, Takahashi E. Tranexamic acid and supportive measures to treat wasting marmoset syndrome. Comp Med. 2016 Dec;66(6):468-73.

10 Moraes IA, Lilenbaum W, Alencar NX, Almosny NP, Cerqueira AM, Uchoa $C$, et al. Wasting syndrome in Saguinus martinsi ("Martin's Bare-face Tamarin") - Callitrichidae - Primates: case report. Acta Vet Bras. 2007;1 (3):94-8.

11 Schroeder C, Osman AA, Roggenbuck D, Mothes T. IgA-gliadin antibodies, IgA-containing circulating immune complexes, and IgA glomerular deposits in wasting marmoset syndrome. Nephrol Dial Transplant. 1999 Aug;14(8): 1875-80.

12 Yoshimoto T, Niimi K, Takahashi E. Serum matrix metalloproteinase 9 (MMP9) as a biochemical marker for wasting marmoset syndrome. J Vet Med Sci. 2016 Jun;78(5):837-43.

13 Sdepanian VL, Moraes MB, Fagundes-Neto U. Doença celíaca: características clínicas e métodos utilizados no diagnóstico de pacientes cadastrados na Associação dos Celíacos do Brasil. J Pediatr (Rio J). 2001 mar-abr;77(2):131-8.

14 Gozalo A, Montoya E. Mortality causes of the moustached tamarin (Saguinus mystax) in captivity. J Med Primatol. 1992 Jan;21 (1):35-8.

15 Kramer JA. Diseases of the gastrointestinal system. In: The common marmoset in captivity and biomedical research. Academic Press; 2019. Chapter 13; p. 213-30.

16 Chalifoux LV, Bronson RT, Escajadillo A, Mckenna $\mathrm{S}$. An analysis of the association of gastroenteric lesions with chronic wasting syndrome of marmosets. Vet Pathol. 1982 Sep;19(7 Suppl): 141-62.

17 Logan AC, Khan KN. Case report: clinical pathologic changes in two marmosets with wasting syndrome. Toxicol Pathol. 1996 Nov-Dec;24(6):707-9.

18 Shimwell M, Warrington BF, Fowler JS. Dietary habits relating to 'wasting marmoset syndrome' (WMS). Lab Anim. 1979 Apr;13(2):139-42. 